\title{
Total Quality Management - Organizations role and support of employees
}

\author{
Hossain A. Alghamdi ${ }^{1}$, Mohammed A. Alfarhan², Reda Samkari ${ }^{3}$ and Syed Hamid Hasan ${ }^{4}$ \\ ${ }^{1,2,3 \& 4}$ Faculty of Computing and Information Technology, Department of Information Systems \\ King Abdulaziz University, Kingdom of Saudi Arabia \\ fcitkau786@gmail.com
}

\begin{abstract}
Nowadays most of known organizations are obsessed with product and service "quality" since customer's orientation has been shifted from product \& service price to its quality. Thus, most of the organizations are willing to adopt the TQM concept and processes in order to achieve their objectives, meet their customer's expectations and attain competitive advantage. TQM is a management philosophy that seeks to integrate all organizational functions to focus on meeting customer needs and organizational objectives.

In this paper we will highlight the organization role and the support of the employees to reach the maximum degree of the TQM. We will also describe some Asian TQM case studies in order to summarize the most important factors for successful TQM implementation.
\end{abstract}

Keywords: TQM (Total Quality Management), CSF (Critical success factors), Organizations role, Employee empowerment.

\section{Council for Innovative Research}

Peer Review Research Publishing System

Journal: International Journal of Management \& Information Technology

Vol. 7, No. 3

editor@cirworld.com

www.cirworld.com, member.cirworld.com 


\section{INTRODUCTION}

Nowadays customers are more quality conscious than the price for purchasing goods or services. Quality and reliability have become overriding factors for the customers in their buying decision. Meeting customer's specifications, dependability of service and speed of delivery are very distinguishing features for the success of an organization. The primary role of management is to lead an organization in its day-to-day operations as well as to maintain it as a viable entity in the future. Quality has become an important factor to success in this strategic responsibility. Providing high quality was recognized as a key element for success [1].

"Total Quality Management (TQM) is a philosophy that involves everyone in an organization in a continual effort to improve quality and achieve customer satisfaction" [2]. Total quality management or TQM refers to structures of applications with organized or methodical outcome on organization practices and effectiveness [7].

There are two key philosophies in TQM, one is a never ending push to improve and the other is a goal of customer satisfaction which involves meeting or exceeding customer expectation. [1]

\section{TQM CONCEPT}

TQM is a management philosophy that seeks to integrate all organizational functions (marketing, finance, design, engineering, and production, customer service, etc.) to focus on meeting customer needs and organizational objectives [9]. The key concepts in the TQM include: [4]

- "Quality is defined by customers' requirements."

- "Top management has direct responsibility for quality improvement."

- "Increased quality comes from systematic analysis and improvement of work processes."

- "Quality improvement is a continuous effort and conducted throughout the organization."

(Figure 1) is illustrating the TQM concept.
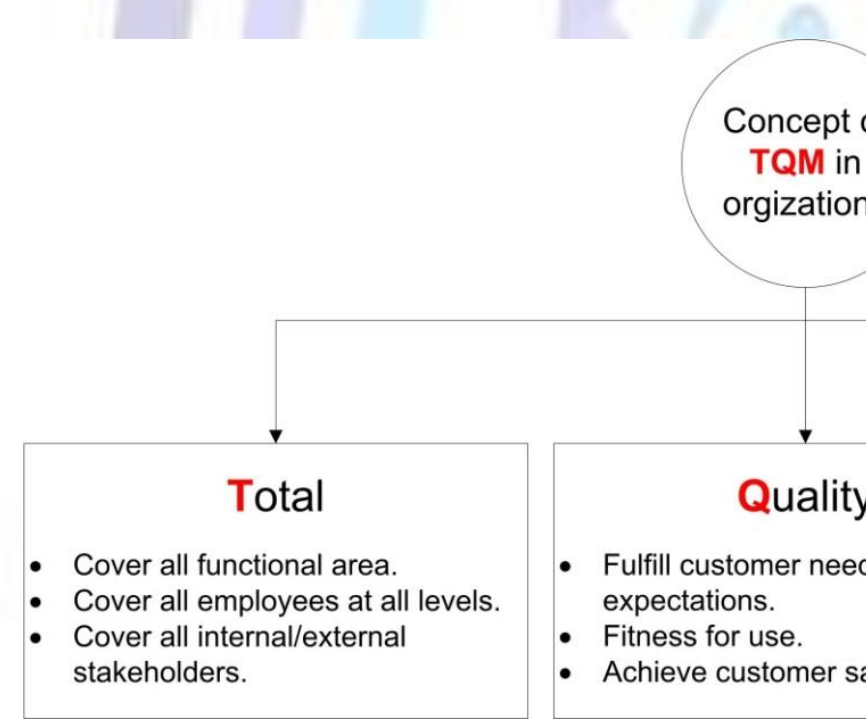

Concept of

TQM in

orgizations
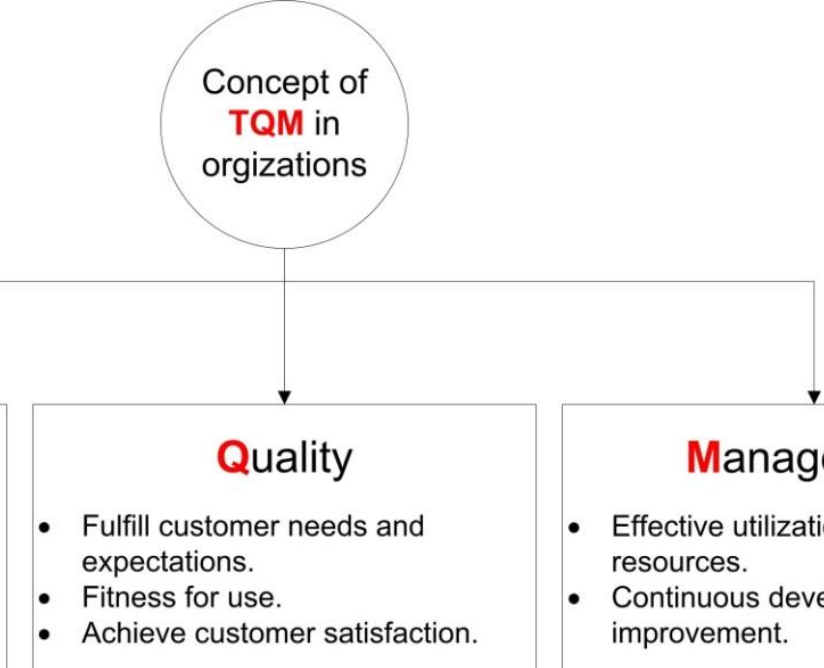

\section{Management}

- Effective utilization of all resources.

- Continuous development and improvement.

Figure 1. TQM concept

\subsection{Historical background}

The quality movement during the 20th century has led to the evolution of TQM. Historically, this evolution is classified in four distinct stages:

1. Quality inspection

2. Quality control

3. Quality assurance

4. Total Quality Management

Each stage has variety of characteristics as illustrated in below (table 1) [10], throughout this period of ongoing development (i.e. 1910s to 1990s), TQM had advanced and developed through the influence of many differing 
factors. TQM has moved from a mainly narrow and mechanistic approach to a more subjective and broader organizational philosophy [11].

Table 1. Characteristics of TQM historical stages

\begin{tabular}{|c|c|}
\hline Stage & Characteristics \\
\hline QI (1910s) & $\begin{array}{l}\text { Salvage; Sorting; Corrective } \\
\text { action; Identify sources of non- } \\
\text { conformance }\end{array}$ \\
\hline QC (1924s) & $\begin{array}{l}\text { Quality manual; Performance } \\
\text { data; Self-inspection; Product } \\
\text { testing; Quality planning; Use of } \\
\text { statistics; Paperwork control }\end{array}$ \\
\hline QA (1950s) & $\begin{array}{l}\text { Third-party approvals; Systems } \\
\text { audits; Quality planning; Quality } \\
\text { manuals; Quality costs; Process } \\
\text { control; Failure mode and effect } \\
\text { analysis (FMEA); Non-production } \\
\text { operation }\end{array}$ \\
\hline TQM (1980s) & $\begin{array}{l}\text { Focused vision; Continuous } \\
\text { improvements; Internal customer; } \\
\text { Performance measure; } \\
\text { Prevention; Company-wide } \\
\text { application; Inter-departmental } \\
\text { barriers; Management leadership }\end{array}$ \\
\hline
\end{tabular}

\subsection{Organization role and support of employee}

\section{- Senior management role}

Senior management is a group of high level executives that actively participate in the daily supervision, planning and administrative processes required by a business to help meet its objectives. The senior management of a company is often appointed by the corporation's board of directors and approved by stockholders [14].

They are sometimes referred to as executive management, top management, upper management, higher management, or simply executives within the corporation [15]. The need for senior management commitment and leadership is recognized by most prominent writers in the area of quality.

TQM implementation must be started by the senior management because they are the primary internal change agent for quality improvement. Furthermore, they must realize that TQM is a long-term business strategy.

The senior management has two major roles [11]:

1. They are shaping organizational values and establishing a managerial infrastructure to actually bring about change.

2. They have to prepare themselves with knowledge about the criteria of TQM and put in their mind the TQM agenda.

Beside the required support and involvement by the seiner management, TQM implementation needs commitment to quality and continuously improving from all levels of staff [12].

\section{- Employee empowerment:}

Empowerment means engaging employees (individual or team) in the decision making processes of an organization and giving their input a seriously consideration. It requires a change in an organization culture and training employees before start forming self-managing teams. 
Employee Empowerment does not imply that executives have to give up their responsibility or authority, while it is a shift in the responsibility, to control the processes and not the individual team members. Also, the management should keep in mind that a decision comes from their own organization. It is an evidence of the management's trust in the employees. [1]

A team work and an employee empowerment are essential for the effective utilization of resources, man power. It was proved that productivity increased by empowerment by 30 percent [13]. Empowerment should be given to teams; each team member should be given a chance to act mentally to achieve their goal or targets. This improves problem solving skill and encourages innovation as employees have the authority to try out new ideas and make decisions. Furthermore, feeling of ownership and responsibility will rise [1].

In addition, job satisfaction can be improved by the leadership and commitment of the top management to the TQM goal of customer satisfactions. They have to create an organizational climate that emphasizes total quality and customer satisfaction.

Empowerment should be structured and planned to achieve the goal in the TQM way. Thus, employees must know their boundaries and align their contribution/ decision with management philosophy approach to customer satisfaction and organization's vision and mission

Organization must work on improving a suggestion system that involves improving both the system and individual suggestions. Employees are often in the best position to make suggestions for work place improvements.

A Good suggestion system should have the following [13]:

- All suggestions receive a formal response

- All suggestions are responded to immediately

- Monitored participation, system costs and savings.

Poor suggestion can be handled without damaging morale by listening carefully, expressing appreciation, carefully explaining your position, encouraging feedback and looking for compromise.

In TQM organization, recognizing employee achievement is essential, the organization should reward team as much as possible. In the other hand, rewarding individuals shouldn't affect team's bond \& trust.

Removing hidden barriers, encouraging new employees and coaching reluctant employees will increase the value of the suggestion system.

\section{- Employees' Role:}

\section{- Employees role in implementing TQM as an organizational strategy:}

To achieve the ideals of TQM, employees have to understand it as a corrective and developmental strategy for the good of all stakeholders in the organization. This will involve the employees participating in processes of reengineering, new ways of doing things, and communicating their ideas to management. For employees to practice this level of commitment and involvement, it is imperative that management consciously transfer skills and the power to take necessary decisions, to them. Workers must believe that management genuinely trusts them with the custodianship for quality achievement and continuous improvement [15].

Employees also have the responsibility to identify quality defects, as well as to proactively recognize threats to quality and continuous improvement. To be able to do this, employees need to have no fear of reprimand or discipline from management for failing to achieve total quality. Managers need to create a culture of learning and freedom to make mistakes in the process of learning [15].

- Employees role in sharing in organizational goals:

How successful an organization is will depend on the commitment of its people to achieve the goals that an organization has set for itself. The ideal is that individuals within the organization also set goals for themselves that coincide with organizational goals, so that employees can be motivated 
by them. For example, it has been found that there is a mutual relationship between employee satisfaction and customer satisfaction, where satisfied customers can reinforce the employees' sense of satisfaction in their jobs [16].

Another motivator in encouraging people to share in the organizational goals is identification. Personal identity is the most important thing that humans possess. It is the way humans feel about themselves, the way they express themselves, and the way other people see them. This is the core of what makes individuals unique. The realization of the importance of this identity for managers is fundamental for people management. People like to be recognized for what they are, what they uniquely possess, and what their specific contribution can add to business. This is a major motivator towards continuous improvement and total quality [15] [17].

- Employees role in investing their talents for the benefits of their team and the organization:

Employees have a responsibility to invest their talents within their organizations, making an effort to share in organizational goals, and actively working towards the implementation of the company strategy. On the other hand, employers have to take responsibility for the maximization of employee's productivity, striving for commitment rather than compliance, and respecting the employees' need to make a difference [15].

One of the ways of winning the war for talent, as identified by most TQM gurus, is the team approach. Teams are a very important TQM output vehicle as varying styles, interests and skills of employees are used to complement one another for the achievement of team goals and thereby organizational goals. Within the team, feelings of belonging, sharing, togetherness, caring and friendliness, create an enjoyable working atmosphere with the mutual support and cooperation that helps to reduce the pressures and stress on individual members, especially the group leaders [15].

\section{LESSONS LEARNED FROM TQM IMPLEMENTATION IN ASIAN ORGANIZATIONS}

Critical Success Factors as critical areas which organization must accomplish to achieve its mission by examination and categorization of their impacts and thus require special attention for implementation of Total Quality Management [6]. Successful TQM implementation enables SMEs to achieve dramatic gains in business performance [5].

TQM implementation is a difficult, comprehensive, and long term process. Leaders need to maintain their commitment, keep the process visible, provide necessary support, and hold people accountable for results [3].

A study has been conducted in Iranian context and the findings indicate that top management commitment, strategic quality planning, process management and training, are drivers and respectively are of high importance. On the other hand, customer focus, employee involvement, supplier management, product and service design, and quality culture are dependent factors [5].

Another study has been conducted on Malaysian semiconductor manufacturing firm to determine the role of TQM in the firm and determined the key contributing variables of TQM. Overall, it has been noticed that the role of TQM is relatively strong and stable in this firm. Specifically, it is identified that leadership, customer/supplier relations and employee relations are needed to be focused upon more not only due to their strong involvement in the other variables of total quality management, but also due to their vast opportunities to further be improved in the future. Thus, these components play an tremendously significant role in enhancing engineering performance, more emphasis on them is still needed to further improve the implementation of TQM to its' fullest extent [8].

It can be concluded from mentioned studies that the most critical success factors in TQM implementations are:

1. Top management commitment / Leadership.

2. Strategic quality planning.

3. Process management.

4. Training.

5. Employee involvement.

6. Vendor/Supplier management.

7. Product and service design.

8. Organizational culture.

\section{CONCLUSION}

TQM is a long term organization strategy and it is not only target the products or the services but it covers process quality, productivity, costs, development and participation of all employees at all levels. 
Controlling organization TQM is a preventive process rather than series of treatment actions. Thus, defining successful business processes that accommodate organization needs and goals will definitely lead to design the suitable TQM processes which will result in achieve customer expectations.

Continues development and frequent benchmarking for the TQM processes will guide the top management in taking the right decisions at the right time.

Quality is responsibility of all organization members especially the top management. Hence, the top management role is not only limited to taking the decisions but also they need to make sure that all organizations members are aligned with the TQM process and goals. So, any organization plans to adopt TQM need to ensure a well communications and awareness among all teams at all levels.

\section{REFERENCES}

[1] Dr. Santoshkumar Badiger, Dr. Rajnalkar Laxman; "Total Quality Management and Organisation Development”; International Journal of Business and Management Invention; Volume 2 Issue 7, July 2013, PP.34-37

[2] Summers, Donna; "Quality"; Pearson Education, Inc.; 2009.

[3] Jalel Ben Hmida*, Anthony J. Gaspard, Jim Lee; "TQM-Based Equipment Maintenance in Oilfield Service Industries"; Global Perspectives on Engineering Management, Vol. 2 Iss. 2, PP. 60-6; May 2013.

[4] Houston, Archester; "A Total Quality Management Process Improvement Model”; San Diego, California: Navy Personnel Research and Development Center, pp. vii-viii, OCLC 21243646, AD-A202 154; (December 1988)

[5] Jamali G. ,Ebrahimi M. , Abbaszadeh M.A. ; "TQM Implementation: An Investigation of Critical Success Factors"; Education and Management Technology (ICEMT), 2010 International Conference - E-ISBN : 9781-4244-8618-2; Nov 2010.

[6] I.S. Salaheldin; "Critical Success Factors for TQM Implementation and their Impact on Performance of SMEs"; International Journal of Productivity and Performance Management, Vol. 58, No. 3, 2009, pp. 215237.

[7] M. Mart_nez-Costa, A. R. Mart_nez-Lorente, and T. Y. Choi; "Simultaneous consideration of TQM and ISO 9000 on performance and motivation: An empirical study of Spanish companies"; International Journal of Production Economics, vol. 113, pp. 23-29, 2008.

[8] Poh Kiat Ng, Kian Siong Jee, Nurul Izah Anuar; "The Role of TQM in a Malaysian Manufacturing Firm"; 2012 International Conference on Innovation, Management and Technology Research, Print ISBN: 978-14673-0655-3; May 2012.

[9] C.K.Tewari and Shamit Dias; "Attaining Excellence Through Total Quality Management in Contemporary Era"; VSRD-TNTJ, Vol. I (1), 2010, 35-41

[10] Prof. Alessandro Brun, Alejandro Muñoz Casas; "Total Quality Management : Quality Culture, Leadership and Motivation"; Politecnico Di Milano; 2011

[11] Baba Md. Deros, Mohd Nizam Ab. Rahman, Jaharah A. Ghani,Dzuraidah Abd. Wahab, Mohd. Hazri Hashim and Nor Kamaliana Khamis; "Role of Senior Management in TQM Implementation in Malaysian Small and Medium Enterprises"; Journal - The Institution of Engineers, Malaysia (Vol. 72, No.3, September 2009)

[12] Leonard, D., and McAdam R.; "The strategic impact and implementation of TQM", The TQM Magazine, Vol. 14, No. 1, pp. 51-60, MCB University Press Ltd (2002).

[13] S. Thamizhmanii, S. Hasan; "A review on an employee empowerment in TQM practice"; Journal of Achievements in Materials and Manufacturing Engineering 39/2 (2010) 204-210.

[14] [online] BusinessDictionary.com; "What is senior management definition and meaning".

[15] [online] Wikipedia.com; "Senior management".

[16] M. G. Matlhape, N. Lessing; "Employees in Total Quality Management”; Acta Commercii 2002 Volume 2

[17] Ziethaml \& Bitner; Services marketing. 2nd ed. New York : McGraw-Hill ; 1996.

[18] Cartwright J.; "Cultural transformation: nine factors for continuous business improvement"; London : Prentice Hall; 1999. 